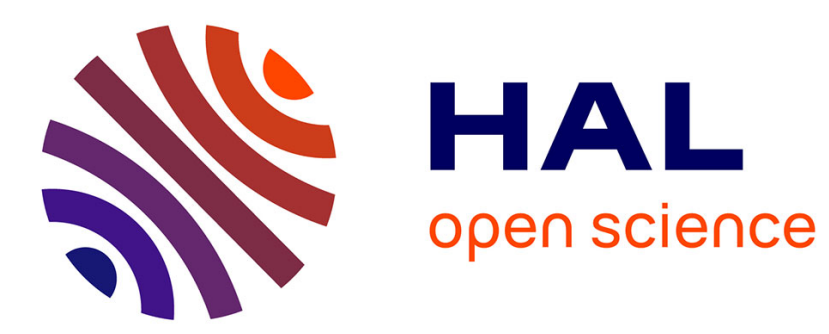

\title{
Extensive gene flow within sibling species in the deep-sea fish Beryx splendens
}

Galice Hoarau, Philippe Borsa

\section{To cite this version:}

Galice Hoarau, Philippe Borsa. Extensive gene flow within sibling species in the deep-sea fish Beryx splendens. Comptes rendus de l'Académie des sciences. Série III, Sciences de la vie, 2000, 323 (Série 3: Sciences de la Vie), pp.315-325. 10.1016/S0764-4469(00)90124-0 . ird-00202209

\section{HAL Id: ird-00202209 \\ https://hal.ird.fr/ird-00202209}

Submitted on 4 Jan 2008

HAL is a multi-disciplinary open access archive for the deposit and dissemination of scientific research documents, whether they are published or not. The documents may come from teaching and research institutions in France or abroad, or from public or private research centers.
L'archive ouverte pluridisciplinaire HAL, est destinée au dépôt et à la diffusion de documents scientifiques de niveau recherche, publiés ou non, émanant des établissements d'enseignement et de recherche français ou étrangers, des laboratoires publics ou privés. 


\section{Extensive gene flow within sibling species in the deep-sea fish Beryx splendens}

Galice Hoarau, Philippe Borsa

IRD and Laboratoire Génome populations interactions, Station méditerranéenne de l'environnement littoral, 1, quai de la Daurade, 34200 Sète, France

Received 26 August 1999; accepted 18 October 1999

Communicated by Jean Rosa

To be cited as:

Hoarau G, Borsa P. 2000. - Extensive gene flow within sibling species in the deep-sea fish Beryx splendens. C.R. Acad. Sci. Paris 323, 315-325. 
Abstract - Molecular markers allow insights into the population biology and ecology of deep-sea organisms, which are usually hardly accessible to direct observation and poorly known. Such a study was undertaken here for the deep-sea fish Beryx splendens, a species of growing interest to fisheries. B. splendens populations were sampled on seamounts and continental margins in the southwestern Pacific (New Caledonia, New Zealand, southeastern Australia) and in the northeastern Atlantic. Two hundred and fifty individuals were characterised by their single-strand DNA conformation (SSCP) of a z 360-base-pair (bp) fragment of the mitochondrial cytochrome b gene, amplified by the polymerase chain reaction (PCR). Two major SSCP haplotypes were observed in New Caledonia, a and $\mathrm{w}$, whose frequencies were negatively correlated along a north-to- south cline. All SSCP haplotypes in the total sample were sequenced on $273 \mathrm{bp}$. The phylogenetic tree of B. splendens haplotype sequences, rooted by two B. decadactylus sequences, showed that a and w belong to distinct mitochondrial clades, A and $\mathrm{W}$, which are separated by z 4-6\% nucleotide divergence. Thirty individuals from New Caledonia were characterised by their DNA fingerprint from arbitrary-primed PCR. The distribution of individualpairwise similarity indices was strongly bimodal. The larger similarity values all corresponded to comparisons within a clade (A or W) while the lower values were all between clades. Therefore, there was a strict association between the mitochondrial type and the DNA (presumably, nuclear DNA) fingerprint of an individual. Altogether, these results point to the existence of two biological species (sp. A and sp. W) within the current taxon B. splendens. No within-species differentiation was detected at the regional scale (New Caledonia). A remarkable result is that the three cytochrome $b$ haplotypes of northeastern Atlantic B. cf. splendens sp. A were also the three commonest in the southwestern Pacific populations of this species. Such a level of homogeneity in the distribution of haplotypes suggests there is, or recently has been, gene flow at the inter-oceanic scale.

Beryx splendens / geographic structure / systematics / cytochrome b / DNA fingerprints

Résumé - Flux géniques élevés chez deux espèces jumelles identifiées chez le poisson de profondeur Beryx splendens. Les marqueurs génétiques moléculaires permettent d'aborder la biologie et l'écologie des populations d'organismes des grands fonds marins, peu accessibles à l'observation directe et en général mal connus. Une telle étude a été ici entreprise chez le poisson de profondeur Beryx splendens, espèce d'intérêt halieutique croissant, dont les populations ont été échantillonnées sur les monts sousmarins et les marges continentales dans le Pacifique Sud-Ouest (Nouvelle-Calédonie, Nouvelle-Zélande, Australie du Sud-Est) et dans l'Atlantique Nord-Est. Deux-cent cinquante individus ont été caractérisés par la conformation ADN simple-brin (SSCP) d'un fragment de z 360 paires de bases (pb) du gène mitochondrial du cytochrome $b$, amplifié par la réaction de polymérisation cyclique (PCR). Deux haplotypes majoritaires ont été observés autour de la Nouvelle-Calédonie, $a$ et $w$. Les fréquences de ces haplotypes étaient corrélées négativement entre elles le long d'un cline nord-sud. Tous les haplotypes SSCP rencontrés dans l'échantillon total ont été séquencés sur une longueur de $273 \mathrm{pb}$. L'arbre phylogénétique des séquences de $B$. splendens, raciné par deux séquences de $B$. decadactylus montre que les haplotypes $a$ et $w$ appartiennent à deux clades mitochondriaux distincts, $\mathrm{A}$ et $\mathrm{W}$, séparés par une divergence nucléotidique de z 4-6\%. Trente individus de Nouvelle-Calédonie ont été caractérisés par leur empreinte génétique obtenue par PCR à l'aide de deux paires d'amorces arbitraires. La distribution des indices de similarité entre profils individuels examinés deux-à-deux est bimodale. Les faibles valeurs de similarité se sont avérées être celles des comparaisons d'individus d'un même clade mitochondrial (A ou W) alors que les valeurs élevées correspondaient aux comparaisons inter-clades. La forte corrélation 
observée entre type mitochondial et empreinte génétique (présumée être nucléaire) permet de conclure que deux espèces biologiques (sp. A et sp. W) sont présentes au sein du taxon B. splendens. Au sein de chaque espèce, aucune différenciation génétique n'a été détectée à l'échelle régionale (Nouvelle-

Calédonie). Un résultat remarquable est que les trois haplotypes du cytochrome $b$ échantillonnés chez $B$. cf. splendens sp. A dans l'Atlantique Nord-Est sont aussi les trois haplotypes majoritaires chez cette espèce dans le Pacifique Sud-Ouest. Une telle homogénéité dans la distribution des haplotypes suggère l'existence d'un flux génique à l'échelle inter-océanique.

\section{Version abrégée}

La biologie des organismes marins de profondeur reste mal connue, en raison de l'inaccessibilité de l'habitat et des difficultés d'expérimentation. L'analyse de la distribution géographique des fréquences des gènes et des génotypes permet d'acquérir des connaissances sur la structure et l'histoire évolutive des populations. Les travaux de génétique ainsi réalisés à ce jour chez les poissons de profondeur ont permis des clarifications de la systématique, rapporté chez certaines espèces des différences génétiques à l'échelle régionale indiquant la présence de barrières au flux génique, ou à l'inverse révélé chez d'autres espèces une remarquable homogénéité à l'échelle mondiale, synonyme de flux géniques élevés d'un océan à l'autre.

Le béryx, Beryx splendens, est un poisson benthopélagique à répartition mondiale qui vit aux alentours des monts sous-marins et sur les pentes continentales à des profondeurs de 200 à $1250 \mathrm{~m}$. Sa phase pélagique durerait jusqu'à plusieurs mois, permettant la dispersion des individus sur de grandes distances. Cependant, les monts sous-marins constituent des habitats isolés, séparés les uns des autres par les immensités océaniques; l'interaction des courants et de la topographie provoque à leur voisinage la formation de tourbillons susceptibles de favoriser la rétention des larves et la concentration de leurs proies, offrant ainsi aux populations locales la possibilité d'auto-recrutement.

Nous avons utilisé un fragment du génome mitochondrial, le gène du cytochrome $b$, comme marqueur génétique de la structure géographique de $B$. splendens sur les monts sous-marins de la NouvelleCalédonie ainsi qu'à l'échelle inter-océanique. L'évolution rapide de l'ADN mitochondrial et son mode de transmission clonal en font un marqueur idéal pour des études phylogéographiques au niveau populationnel. Les données mitochondriales permettent aussi de tester des hypothèses sur la structure géographique des populations. Selon l'hypothèse de panmixie, on s'attend à ce que la distribution des haplotypes soit homogène à l'échelle géographique considérée. Dans le cas de l'isolement par la distance, la structure génétique globale de la population reflète l'état d'équilibre entre le flux génique et la dérive génétique locale, et la distance génétique entre populations croît avec la distance géographique qui les sépare. Chez les espèces exploitées, l'étude de la structure géographique a un intérêt pratique car elle peut aboutir à l'identification des populations ou stocks. Cette délimitation géographique des populations, établie sur des bases biologiques, est nécessaire à la gestion rationnelle des pêcheries.

$B$. splendens est une ressource potentielle importante et la mise en évidence de différentes populations dans la zone économique de la Nouvelle-Calédonie serait essentielle pour en éviter la surexploitation. Des échantillons de Beryx splendens ont été capturés dans la zone économique de la Nouvelle-Calédonie $\left(18^{\circ} 41^{\prime} \mathrm{S}-25^{\circ} 24^{\prime} \mathrm{S} ; 163^{\circ} 14^{\prime} \mathrm{E}-170^{\circ} 10^{\prime} \mathrm{E}\right)$, au large de la côte sud-est de l'Australie, sur la Ride de Chatham au large de la Nouvelle-Zélande ( $\left.42^{\circ} 53^{\prime} \mathrm{S} ; 177^{\circ} 42^{\prime} \mathrm{E}\right)$, et sur le banc de Galice au large de $l^{\prime}$ Espagne $\left(42^{\circ} 37^{\prime} \mathrm{N}-42^{\circ} 41^{\prime} \mathrm{N} ; 11^{\circ} 35^{\prime} \mathrm{W}-11^{\circ} 52^{\prime} \mathrm{W}\right)$. L'ADN total de chaque individu a été extrait selon la technique du phénolchloroforme. Un fragment d'environ 350 paires de bases $(\mathrm{pb})$ du gène du cytochrome $b$ a été amplifié par la réaction de polymérisation cyclique (PCR) à l'aide d'amorces 
universelles. Le polymorphisme de structure secondaire du fragment amplifié a été mis en évidence par la technique de polymorphisme de conformation simple-brin (SSCP). Quatorze haplotypes ont ainsi pu être détectés sur un échantillon total de $n=238$ B. splendens de Nouvelle-Calédonie amplifiés par PCR au locus du cytochrome $b$. Aucun haplotype SSCP supplémentaire n'a été détecté dans les échantillons de $B$. splendens d'Australie $(N=4)$, de la Ride de Chatham $(N=4)$, et du banc de Galice $(N=4)$. Les estimations du $F$ st de Wright montrent que les populations échantillonnées dans le nord de la NouvelleCalédonie sont nettement différentes de celles du sud. Ainsi, nous rejetons l'hypothèse selon laquelle les six populations forment un grand ensemble panmictique. La régression entre la distance génétique de Reynolds ( $D$, transformée du $F$ st) et la distance géographique est positive : nous observons un cline nordsud marqué chez B. splendens en Nouvelle-Calédonie, Deux cent soixante-treize paires de bases du gène du cytochrome $b$ ont été séquencées pour quatorze haplotypes SSCP de Beryx splendens de la NouvelleCalédonie, et deux haplotypes de $B$. decadactylus du golfe de Gascogne et d'Australie. L'arbre de parcimonie des haplotypes, raciné avec les deux haplotypes de $B$. decadactylus utilisés comme groupe externe, présente deux clades distincts $(A$ et $W$ ) au sein du taxon $B$. splendens. Les deux clades sont séparés par une divergence nucléotidique de 4.6-6.7\%. Le clade $A$ comprend un ensemble d'haplotypes SSCP rencontrés en Nouvelle-Calédonie, en Australie, sur la Ride de Chatham et sur le banc de Galice, et différant les uns des autres par 0.4-3.0\% de divergence nucléotidique. Le clade $W$ comprend deux haplotypes, distants l'un de l'autre de $1.1 \%$ de divergence nucléotidique, et n'a été observé que dans les échantillons du nord de la Nouvelle-Calédonie, La présence en sympatrie de deux lignées mitochondriales phylogénétiquement distantes conduit à envisager deux hypothèses : a) la remise en contact de populations géographiquement séparées au cours des temps géologiques, ou b) le mélange dans les échantillons de deux espèces. Selon la première hypothèse, nous serions en présence d'une seule espèce et la phylogénie dichotomique traduirait la remise en contact récente (eu égard au pas de temps nécessaire à l'équilibre mutation/dérive) de deux lignées mitochondriales qui auraient divergé par isolement géographique. (a.a) Sous l'hypothèse supplémentaire que la distribution géographique des fréquences haplotypiques reflète l'état d'équilibre entre flux génique et dérive génétique, le cline abrupt observé signifierait soit un taux de migration efficace extrêmement réduit, soit des tailles efficaces de population extrêmement faibles, soit les deux. (a.b) Alternativement, la remise en contact des deux lignées mitochondriales serait trop récente par rapport au temps nécessaire pour atteindre l'équilibre migrationdérive : il faudrait alors admettre que la zone échantillonnée coïncide précisément avec la zone de contact entre les deux lignées. Bien qu'il soit impossible, sur la seule base des données mitochondriales, de rejeter cette hypothèse (a) et l'une ou l'autre de ses implications selon que l'équilibre migration-dérive est établi ou non, celles-ci sont peu étayées. En effet, chez les espèces marines à longue phase larvaire et présentant une corrélation positive entre distance génétique et distance géographique, le taux de divergence est bien moindre que celui observé ici, à l'exception de quelques rares cas bien documentés de sélection d'allozymes. Ainsi, chez la sole Solea vulgaris, la valeur estimée de $D$ augmente linéairement avec la distance géographique, à raison de 0.01 pour $1000 \mathrm{~km}$ de la Manche à la Mer Egée. Chez les populations insulaires du poisson chirurgien Acanthurus triostegus des Iles de la Société et des Tuamotu-Gambier (Polynésie française), $D$ tend à augmenter avec la distance inter-îles à raison de 0.03 pour $1000 \mathrm{~km}$. Chez le flet atlantique, Platichthys flesus flesus, la valeur estimée de $D$ augmente de 0.008 tous les $1000 \mathrm{~km}$. La même approche, utilisée chez les bivalves Ostrea edulis et Ruditapes decussatus aboutit à des résultats semblables. Ces études ont toutefois porté sur les données de fréquences alléliques à des locus nucléaires. À notre connaissance, les seules données équivalentes à partir de marqueurs mitochondriaux ont été publiées chez l'étoile de mer Linckia laevigata, espèce dont la phase larvaire, pélagique, est de durée comparable à celle de $B$. splendens (de l'ordre du mois) et chez O. edulis (phase larvaire * $10 \mathrm{j}$ ). Chez ces deux espèces, la différenciation génétique croît avec la distance géographique à raison de $0.03 D$ pour 1 $000 \mathrm{~km}$. Chez B. splendens, la pente du cline géographique des fréquences haplotypiques est de $\sim 0.65 D$ 
pour $1000 \mathrm{~km}$, soit un ordre de grandeur dix à cent fois supérieur à celui des espèces passées en revue cidessus. L'hypothèse (a.a) de l'isolement par la distance est difficile à admettre pour cette raison, et aussi parce qu'elle semble incompatible avec l'existence d'haplotypes du cytochrome $b$ identiques au sein d'un des deux clades (le clade $A$ ), échantillonné aux antipodes. L'hypothèse (a.b) selon laquelle le cline des fréquences haplotypiques constituerait un état transitoire suppose que l'étude a été entreprise à l'endroit même de la remise en contact, et que cette dernière est très récente. Dans quelques cas bien documentés d'expansion des aires de distribution d'espèces marines, on peut estimer que la vitesse de colonisation est de l'ordre de 10-100 km/génération, ce qui est très rapide et rend l'hypothèse (a.b) d'autant moins vraisemblable. L'hypothèse (b) suppose que les échantillons consistent en des mélanges de deux espèces jumelles. Selon cette hypothèse, le cline des fréquences haplotypiques serait l'expression d'un cline de présence-absence des deux espèces. Ce cline pourrait correspondre à une zone de contact, peut-être une zone d'hybridation. L'analyse génotypique à un ou plusieurs locus nucléaires permet de départager les scénarios en concurrence. Selon l'hypothèse (b) (deux espèces biologiques), on s'attend à ce que les génotypes nucléaires ne soient pas répartis au hasard dans l'une ou l'autre des deux classes $(A$ ou $W)$ définies en fonction de l'haplotype mitochondrial, et que les individus présumés hétérozygotes entre allèles fixés dans l'un ou l'autre type soient absents ou rares. Selon l'hypothèse (a.a), on s'attend à ce qu'il n'y ait à l'échelle locale aucune corrélation entre génotype nucléaire et haplotype mitochondrial et que les fréquences génotypiques nucléaires soient conformes aux attendus du modèle de HardyWeinberg. Selon l'hypothèse (a.b), l'équilibre migration-dérive n'est pas encore atteint, et on s'attend à observer des gradients de déséquilibres (de Hardy-Weinberg, génotypique, nucléo-cytoplasmique) parallèles au cline des fréquences haplotypiques. Nous avons amplifié par PCR des fragments anonymes d'ADN nucléaire présumé, à l'aide de deux paires d'amorces arbitraires. Les données ainsi obtenues consistent en la présence ou l'absence de produit d'amplification d'une longueur donnée, ou bien en des polymorphismes de longueur présumés. Ces données ont été analysées en comptant le nombre de bandes d'ADN communes entre profils individuels examinés deux-à-deux. La distribution des indices de similarité $\left[S_{\mathrm{XY}}=2 \cdot n_{\mathrm{XY}} /\left(n_{\mathrm{X}}+n_{\mathrm{Y}}\right)\right.$, où $n_{\mathrm{XY}}=$ nombre de bandes $\mathrm{ADN}$ en commun entre les individus $\mathrm{X}$ et $\mathrm{Y}$, $n_{\mathrm{X}}\left(n_{\mathrm{Y}}\right)=$ nombre total de bandes chez l'individu $\mathrm{X}(\mathrm{Y})$ ] est bimodale et disjointe, le mode de droite correspondant aux valeurs intra-clade mitochondrial, et le mode de gauche, aux valeurs inter-clades. La corrélation entre haplotype mitochondrial et génotype nucléaire présumé est très significative (test de Mantel sur la matrice des similarités par paire; $p<0.01$ ). Les deux lignées mitochondriales de $B$. cf. splendens correspondent donc à deux entités reproductivement isolées. L'une des deux espèces (Beryx cf. splendens sp. W) a été échantillonnée en Nouvelle-Calédonie exclusivement, en particulier dans le nord de la zone prospectée. Cette espèce est caractérisée au locus du cytochrome $b$ par l'haplotype $w$ ou par l'haplotype $j$, qui diffère du premier par deux substitutions nucléotidiques (sur $273 \mathrm{pb}$ ). L'autre espèce, $B$. cf. splendens sp. A, est présente dans tous les échantillons. Cette espèce est caractérisée par l'haplotype $a$ ou par l'un des variants qui lui sont apparentés $(b, c, d, e, h, i, k, l, u, x, y)$. Aucune hétérogénéité dans la distribution des fréquences alléliques n'a été observée, au sein de chaque espèce, à l'échelle de la zone économique de la Nouvelle-Calédonie : la valeur estimée du $F$ st global est -0.005 pour les populations de l'espèce $\mathrm{A}$, et -0.002 pour les populations de l'espèce $\mathrm{W}$. Ces deux valeurs correspondent à une totale absence de différenciation à cette échelle géographique. La divergence nucléotidique de $B$. cf. splendens sp. A observée à l'échelle inter-océanique (0.4-2.6\%) est du même ordre que la divergence observée à l'échelle locale (0.4-3.0\%). La présence desmêmes haplotypes dans l'Atlantique Nord-Est, en NouvelleZélande, et en Nouvelle-Calédonie, suggère que les populations de B. cf. splendens sp. A ont une histoire commune récente, ce qui implique un niveau élevé de flux génique (actuel ou récent) à l'échelle interocéanique. Cela s'accorde avec l'apparente absence de différenciation à l'échelle régionale.

Selon la taxinomie actuelle, le genre Beryx Cuvier comprend deux espèces à répartition mondiale : $B$. decadactylus Cuvier et $B$. splendens Lowe. Les résultats du présent travail amènent ainsi à la révision de 
la taxinomie de $B$. splendens en reconnaissant que ce taxon consiste en deux espèces biologiques, et devront être pris en compte pour la gestion de sa pêcherie dans la zone économique de la NouvelleCalédonie et peut-être ailleurs dans le monde. Nous envisageons désormais de rechercher des critères morphométriques diagnostiques pour l'identification des deux espèces, et d'approfondir, à l'aide de marqueurs nucléaires, l'étude génétique des populations dans la zone de sympatrie du Nord de la Nouvelle-Calédonie.

\section{Introduction}

Molecular population genetics allows us to make inferences on the biology and the ecology of organisms; the phylogeny of genes, combined with their geographic distribution, allows us to reconstruct the temporal sequence of past colonisation and radiation events. Molecular markers are especially useful in organisms whose distribution, biology and ecology are poorly known because of inaccessibility of their habitats, hampering direct observation or experimentation; a good example is the deep sea [1]. Genetic studies on deep-sea fishes have thus clarified their systematics, as in the grenadiers Coryphaenoides armatus and C. yaquinae, whose respective geographic distributions and depth preferences have also been shown to be distinct [2]. Some studies have reported genetic differences at the regional scale, as in the hoki Macruronus novaezelandiae [3]. Other studies have revealed remarkable homogeneity at a global scale, as in the orange roughy Hoplostethus atlanticus and in C. armatus [3-6].

The alfonsino Beryx splendens Lowe, 1834 is present on seamounts and on continental slopes at tropical and temperate latitudes of the world's oceans, at depths between 200 and $1250 \mathrm{~m}[1,7,8]$. It has high fecundity (270 000-700 000 eggs per spawn [9]). Its larvae and juveniles are pelagic, at depths of 50-200 $\mathrm{m}$. The pelagic phase may last several months $[9,10]$ allowing long-distance dispersal. On the other hand, seamounts form scattered habitats that are separated from one another by ocean immensities; in the vicinity of seamounts, the interaction of circulation with topography induces Taylor columns [11], gyres that may cause the retention of larvae and of their prey, favouring self-recruitment of local populations [12].

We used a fragment of the mitochondrial genome, the cytochrome $b$ gene, as a genetic marker of the geographic structure of Beryx splendens on the seamounts and the island slope of New Caledonia, and at the interoceanic scale (southwest Pacific and northeast Atlantic). The fast rate of evolution of the mitochondrial DNA, its clonality and its uniparental mode of inheritance make this marker appropriate for infraspecific, phylogeographic studies [13-15]. Mitochondrial DNA data allow the testing of hypotheses concerning the geographic structure of populations. Under the hypothesis of panmixia, the distribution of mtDNA haplotypes is expected to be homogeneous across samples. Under the hypothesis of isolation by distance, where the genetic structure of the population reflects a steady state of equilibrium between gene flow and genetic drift [16], genetic distance is expected to be positively correlated with geographic distance [17]. The genetic analysis of geographic structure is of particular interest in exploited species because this approach may lead to the delineation of sub-populations or stocks, a prerequisite for fisheries management [18-21]. Stock delineation is desirable for sound management of the Beryx splendens fishery which has started in the economic zone of New Caledonia and neighbouring countries [22-25]. While undertaking this survey, we found that the current taxon Beryx splendens consists of two sympatric species in New Caledonia. This finding questions the current systematics and taxonomy of the genus Beryx. 


\section{Materials and methods}

Alfonsino, Beryx splendens, samples were obtained using bottom lines or bottom trawls at depths between 448 and $936 \mathrm{~m}$ during Cruise HALICAL1 of R/V Alis [24] and Cruise HALIPRO2 of R/V Tangaroa [25], at six sampling sites off New Caledonia (18 $41^{\prime}$ 'S $-25^{\circ} 24^{\prime} \mathrm{S}$; $163^{\circ} 14^{\prime} \mathrm{E}-170^{\circ} 10^{\prime} \mathrm{E}$ ) (figure 1). Two other alfonsino samples were obtained by scientific trawling operations on the Chatham Rise east of New Zealand (42 $53^{\prime} \mathrm{S}$; $\left.177^{\circ} 42^{\prime} \mathrm{E}\right)$, and on the Galicia Bank west of Spain $\left(42^{\circ} 37^{\prime} \mathrm{N}-42^{\circ} 41^{\prime} \mathrm{N}\right.$; $\left.11^{\circ} 35^{\prime} \mathrm{W}-11^{\circ} 52^{\prime} \mathrm{W}\right)$. Another sample, from southeastern Australia, consisted of three individuals purchased by G. Yearsley (CSIRO, Hobart) at the Sydney fish market and one individual caught east of Maria Island (42 $43^{\prime}$ 'S; $148^{\circ} 25^{\prime} \mathrm{E}$ ), now deposited under no. H4222.02 at CSIRO in Hobart. Three $B$. decadactylus individuals from the Gulf of Biscay were sampled at the fish landing site of Ile d'Yeu, France, and another $B$. decadactylus individual was trawled off eastern Tasmania by G. Yearsley. A piece of z 0.1 -cm 3 muscle tissue was dissected from each individual and preserved in $95 \%$ ethanol. Total genomic DNA was extracted using the phenol-chloroform protocol [26], and resuspended in deionised water for later use as template for polymerase chain reaction (PCR). A ca. 350-base-pair (bp) fragment of the cytochrome $b$ gene was PCR-amplified using universal primers $C B 1-L$ (5'-

ATCCAACATCTCAGCATGATGAAA-3') and CB2-H (5'-CCCTCAGAATGATATTTGTCCTCA-3') $[27,28]$ according to protocols previously detailed [29]. Sequence polymorphism of the amplified fragment was evidenced by differential migration of single-stranded DNAs in vertical non-denaturing polyacrylamide gels (SSCP) [30,31]. The SSCP technique is presumed to reveal about $90 \%$ of sequences for 300-bp to 450-bp fragments when these differ from one another by as little as one nucleotide change ([32] in [33]). Details on the migration and DNA-staining procedures have been reported elsewhere ([29], modified from [34]). Cytochrome $b$ haplotypes that were detected by SSCP were first purified by incubating $5 \mu \mathrm{L}$ of PCR product for $15 \mathrm{~min}$ at $37^{\circ} \mathrm{C}$ in $10 \mathrm{U}$ exonuclease I and $2 \mathrm{U}$ shrimp alkaline phosphatase (Amersham Life Science, Cleveland OH, USA), and then sequenced using the Thermosequenase kit (Amersham) according to the standard kit protocol, with either fluorescent primers or radioactively (33P)-labelled dideoxynucleotides. Fluorescent sequence reaction products were run in 6 $\%$-acrylamide (Bio-Rad, Hercules CA, USA)/42 \%-urea polyacrylamide gels in an automatic ALF sequencer (Pharmacia Biotech, Uppsala, Sweden). Radioactive sequence reaction products were run in vertical $6 \%$-acrylamide $/ 42 \%$-urea polyacrylamide gels, the gels dried in a vacuum gel-heater, and exposed against X-Omat film (Eastman Kodak, Rochester NY, USA). Anonymous DNA fragments (presumably nuclear DNAs) were PCR-amplified using the direct, arbitrary primers DALP234 (5'GTTTTCCCAGTCACGACCAG-3') and DALP241 (5'-GTTTTCCCAGTCACGACTCAG-3') in combination with the reverse, arbitrary primer DALP (5'-GTTTTCCCAGTCACGAC-3') [35]. DALP primers have been designed as a 17-bp core made of Phage M13 universal sequencing primer, to the 3'end of which three or four randomly chosen nucleotides are added [35]. DALP-PCR products usually consist of 5-20 DNA bands in the range of sizes comprised betweenz100 andz1 kb, a proportion of which exhibit presence/absence or length polymorphism, thus allowing individual DNA fingerprinting [35]. Just before the PCR, the reverse primer $D A L P$ was radioactively labelled by incubating, for $30 \mathrm{~min}$ at $37^{\circ} \mathrm{C}, 2$ $\mu \mathrm{M}$ primer together with $0.05 \mathrm{mCi}[\gamma-33 \mathrm{P}] \mathrm{ATP}$ (Isotopchim, Ganagobie, France) and $1 U \mathrm{~T} 4$ polynucleotide kinase (Eurogentec, Liège, Belgium). Approximately 1-10 ng genomic DNA was PCRamplified in $20 \mu \mathrm{L}$ reaction mixture including $1.8 \mathrm{mM} \mathrm{MgCl} 2,100 \mu \mathrm{M}$ each dNTP, $0.25 \mu$ Meither direct $D A L P 234$ or DALP241 primer, $1 \mu \mathrm{M}$ radioactively labelled reverse primer DALP, and 0.5 UTaqpolymerase (Promega, Madison, WI, USA) in its buffer. The parameters of the PCR program are as detailed previously [25]. PCR products were run in vertical polyacrylamide gels and autoradiographed on Eastman-Kodak's Biomax film [29]. 
Geographical variation in haplotype frequencies was analysed by estimating Weir and Cockerham's $\theta$ ( $\equiv$ Wright's $F_{\mathrm{ST}}$ ) [36]. Genetic distances between populations were estimated as $\mathrm{D}=-\ln (1-\wedge \theta)$ [37]. The correlation between pairwise $\mathrm{D}$ and the corresponding geographic distances was tested by means of Mantel's permutation test [38]. The FSTATS and MANTEL procedures of the GENETIX software [39] were used to estimate $\theta$, to test their significance using random permutations and to perform Mantel's test of correlation. The partial sequences of the cytochrome $b$ gene were edited and aligned using ESEE 3s [40]. Parsimony analysis was conducted on the matrix of haplotype sequences using the heuristic parsimony algorithm implemented in PAUP 3.3 [41]. The robustness of the inferred phylogeny was tested by bootstrap resampling [42] using option BOOTSTRAP of PAUP 3.3. Nucleotide divergences between haplotypes were estimated using MEGA [43] according to Kimura's two-parameter model [44], where the ratio of transitions on transversions was set to 4. DALP fingerprints were analysed by counting the proportion of shared PCR bands using the similarity index $S_{\mathrm{XY}}=2 \cdot n_{\mathrm{XY}} /\left(n_{\mathrm{X}}+n_{\mathrm{Y}}\right)$ [43], where $n_{\mathrm{XY}}$ is the number of PCR bands in common between individuals $\mathrm{X}$ and $\mathrm{Y}$, and $n_{\mathrm{X}}\left(n_{\mathrm{Y}}\right)$ is the total number of PCR bands in $\mathrm{X}(\mathrm{Y})$. The similarity values were sorted according to whether individuals $\mathrm{X}$ and $\mathrm{Y}$ belonged to the same mitochondrial clade or not. The corresponding distributions were compared by a Mantel test.

\section{Results}

Fourteen SSCP haplotypes were detected in a total sample of 238 Beryx splendens from New Caledonia, amplified by PCR at the cytochrome $b$ locus (table I). The samples from Mounts K and Aramis were characterised by the same, common haplotype $(a)$ and possessed a few rare haplotypes. The sample from Grand Passage was dominated by another haplotype, $w$. The frequencies of haplotypes $a$ and $w$ in samples Astolabe, Lifou and Stylaster were intermediate between these two extremes. Some population-pairwise $\mid \theta$-values were significantly different from zero (table IV of [29]). This result led us to reject the hypothesis that the six samples belong to a single, panmictic population. The genetic distance, D [37] between samples was positively correlated with their geographic distance, $d(\mathrm{D}=0.7 \times 10-3 d-0.142$; Mantel's test, 5000 permutations: $P<0.05$ ).

Two hundred seventy three base pairs of the cytochrome $b$ gene were sequenced in 14 Beryx splendens haplotypes ( $a, b, c, d, e, h, i, j, k, l, u, w, x, y)$, all from individuals sampled in New Caledonia, and two $B$. decadactylus haplotypes, one from the northeastern Atlantic, the other one from eastern Tasmania. The 16 sequences were perfectly aligned, without insertion or deletion. The partial sequences of haplotypes $b$ and $c$ of New Caledonian B. splendens were identical to that of haplotype $y$. All B. splendens haplotype sequences have been deposited in GenBank (accession numbers AF183876 to AF183889). (See also figure 7 of [29]). Figure 2 presents the parsimony tree inferred from the sequence data. This tree featured two clades, one (W) comprising haplotypes $j$ and $w$ distant from each other by $1.1 \%$ nucleotide divergence, and the other (A) comprising the other 12 haplotypes. Within clade A, the branches were short, nucleotide divergence between haplotypes ranged from 0.4 to $3.0 \%$, and the phylogenetic relationships between haplotypes were not resolved. The two clades were separated by $4.0-6.2 \%$ nucleotide divergence. This tree topology and these nucleotide divergence values are very uncommon at the infraspecific level in marine fishes (e.g. [48]). This, and subsequent results led us to consider the two clades separately for re-estimating ${ }^{\wedge} \theta$-values among populations: ${ }^{\wedge} \theta=-0.005$ for all New Caledonian populations of type $\mathrm{A}$, and ${ }^{\wedge} \theta=-0.002$ for those of type $\mathrm{W}$. These two values correspond to a total lack of differentiation within each clade at the local (New Caledonian) scale. Pairwise nucleotide divergences within clade A sampled across oceans ranged between 0.4 and $2.6 \%$. 
The total genomic DNA of 20 individuals of mitochondrial type A and ten individuals of mitochondrial type $\mathrm{W}$ was PCR-amplified using two DALP primer pairs (DALP234/DALP and DALP241/DALP). This analysis yielded complex banding patterns (presented in [29]) which we subsequently treated as individual fingerprints. The distribution of individual-pairwise similarity values was strongly bimodal (figure 3 ). The larger similarity values nearly all corresponded to comparisons within a clade. The lower similarity values all corresponded to inter-clade comparisons (figure 3 ). This distinction was supported by a Mantel test (2 000 permutations; $P<0.01)$. Fingerprint patterns among individuals of a given mitochondrial type ( $\mathrm{A}$ or $\mathrm{W}$ ) were therefore homogeneous, relative to the variation encountered when comparing individuals of types $\mathrm{A}$ and $\mathrm{W}$. In other words, there was a strict association between the mitochondrial type and the DALP fingerprint of an individual.

\section{Discussion}

The phylogenetic tree of cytochrome $b$ gene sequences in Beryx splendens featured two distinct mitochondrial lineages that were separated from each other by $\sim 4$ to $\sim 6 \%$ nucleotide divergence. Under the hypothesis of a molecular clock of $0.5-2 \%$ per million year (MY) [49], these two lineages may have diverged z 2-12 MY ago. B. splendens is a poikilothermic species of cold habitat, with a long generation time $[8,9]$, slow growth $[8,50,51]$, and hence, presumably, slow metabolism. These characteristics are those of vertebrates with a slow mtDNA clock $[52,53]$. The lower limit of the interval of molecular divergence rates proposed by Avise et al. [49], that is $0.5 \%$ per MY, thus may still be overestimated. The sympatric presence of two phylogenetically distant mitochondrial lineages leads us to propose the following two hypotheses: a) recent secondary contact of populations that have been geographically separated for a long period, or b) admixture in the samples of two sibling species [14].

- Hypothesis (a): strong genetic structuring within species. This hypothesis states that only one Beryx splendens species is present around New Caledonia, and that the dichotomy in the mitochondrial phylogeny reflects recent secondary contact of two lineages that have diverged by geographic isolation.

(a.a) Under the additional hypothesis of equilibrium between genetic drift and gene flow, the abrupt cline of haplotype frequencies would reflect either limitation in gene flow, or extremely low effective population sizes $(\mathrm{Ne}$ ) or both. (a.b) Conversely, the secondary contact would be too recent for the migration/drift equilibrium to be reached, in which case the location and timing of sampling around New Caledonia would precisely coincide with the contact between the two lineages. Mitochondrial-DNA data alone are not sufficient for rejecting hypotheses (a.a) or (a.b), but these hypotheses do not appear to be supported by evidence from comparisons with other marine species with long pelagic stage. Apart from a few documented cases of secondary contact (e.g. [13]), steep geographic clines reported so far in such species (e.g. mussel Mytilus edulis and killifish Fundulus heteroclitus) are not thought to be caused by restricted gene flow or low effective $\mathrm{Ne}$ but by strong selection at allozyme loci [54]. Clines that are thought to reflect isolation by distance are much smoother than that reported here. For instance, in the common sole, Solea vulgaris, the estimate of D increases linearly with geographic distance at a rate ofz0.01 per $1000 \mathrm{~km}$ from the English Channel to the Aegean Sea [55, 56]. In island populations of the surgeonfish Acanthurus triostegus of the Society and the Tuamotu-Gambier archipelagoes, D tends to increase by z 0.03 for $1000 \mathrm{~km}$ between-island distance [57]. In the Atlantic populations of the flounder Platichthys flesus flesus, D increases by z 0.008 every $1000 \mathrm{~km}$ [58]. Similar results can be inferred or have been reported for two bivalve species from the northeastern Atlantic and the Mediterranean, the flat oyster Ostrea edulis and the palourde Ruditapes decussatus [59-61]. These studies, however, were all concerned with allele frequency variation at nuclear loci (allozyme and microsatellite). To our 
knowledge, the only regressions of mitochondrial genetic distance against geographic distance in marine organisms with long pelagic stage have been undertaken in the seastar Linckia laevigata (pelagic duration * 1 month) and in $O$. edulis (*10 d). In both cases the genetic distance increased with geographic distance by $\sim 0.03 \mathrm{D}$ per $1000 \mathrm{~km}[62,63]$. In $B$. splendens, the geographic cline of haplotype frequencies was $>20$ times steeper than in the above species. Hypothesis (a.a) (i.e. isolation by distance) is hard to admit for this reason, and also because this hypothesis is hardly compatible with the worldwide distribution of haplotypes $a, h$ and $i$. Hypothesis (a.b), according to which the haplotype frequency cline would be transitory, supposes that the sampling was undertaken at the very place of secondary contact, and that the latter is very recent. The rate of colonisation of marine species with long pelagic stage is on the order of 10-100 km per generation [64], which is very fast and renders hypothesis (a.b) as highly unlikely.

- Hypothesis (b): sibling species. Sibling species are frequent in the sea, especially in the deep sea $[1,65]$. According to this hypothesis, the cline of haplotype frequencies in Beryx splendens would reflect the admixture in variable proportion of two reproductively isolated entities, $B$. cf. splendens sp. A and $B$. cf. splendens sp.W. This cline may correspond to simple contact between species, or perhaps to a hybrid zone. Genotypic analysis at polymorphic, nuclear loci would allow a definitive test. Under hypothesis (a.a), at the local scale there should be no correlation between nuclear genotype and mitochondrial haplotype, and nuclear genotype frequencies should conform to the Hardy-Weinberg model. Under hypothesis (a.b), the migration/drift equilibrium would not be reached, and one expects to observe HardyWeinberg, genotypic [66], and nucleo-cytoplasmic [67] disequilibrium gradients parallel to the haplotype frequency cline. Under hypothesis (b) (sibling species), nuclear genotypes are expected to be heterogeneously distributed among mtDNA (A or W) classes of individuals, and heterozygotes between the species-specific alleles should be rare or absent. We observed a significant correlation between DALP fingerprint and mitochondrial clade. Arbitrary-primed PCR fingerprints (presumably nuclear [35]) thus confirmed that the mitochondrial clades A and W characterise individuals of different species. Species W was sampled in New Caledonia only, mostly in the north of the area sampled; species A was sampled in New Caledonia, on the Chatham Rise off New Zealand, off southeastern Australia, and on the Galicia Bank in the northeastern Atlantic. No heterogeneity in the distribution of haplotype frequencies was observed within either Beryx cf. splendens species A orW at the scale of New Caledonia. The presence of the same SSCP haplotypes $(a, h, i)$ in both the northeastern Atlantic and the southwestern Pacific suggests that $B$. cf. splendens sp. A populations share a recent evolutionary history at the worldwide scale, which in turn implies inter-oceanic gene flow. Some other deep-sea fishes (Coryphaenoides armatus, Hoplostethus atlanticus) also show remarkable genetic homogeneity at the inter-oceanic scale [4-6]. In deep-sea species such as $B$. splendens, gene flow can be due to recent or present stepwise migration along oceanic ridges and continental margins, or to transoceanic expansion of the species' range. According to current taxonomy, the genus Beryx Cuvier includes two species, B. decadactylus Cuvier and B. splendens Lowe, both with worldwide distribution. Taxonomy reflects our perception of morphological distance between specimens. Since this genus is known for its extreme morphological conservatism [68], we hypothesise that morphological characters are not powerful enough for full systematic resolution, thus explaining why B. splendens so far has been considered as monotypic [69]. The molecular identification of two species within the current taxon $B$. splendens will have obvious consequences on the systematics and the taxonomy of the genus. Fishery management of $B$. cf. splendens in New Caledonia and perhaps elsewhere will have to take the present findings into account. In this respect, it would now be useful to be able to identify the two species using morphometric characters.

Acknowledgements: This project was initiated by R. Grandperrin from IRD, following his and P. Lehodey's surveys of Beryx splendens on the seamounts south of New Caledonia. We are grateful to R. 
Grandperrin for discussions and support, for organising sampling trips, collecting, and providing HALICAL 1 and HALIPRO 2 samples, and for arranging the collection of samples on the Chatham Rise and the Galicia Bank; to F. Bonhomme from CNRS/Laboratoire génome populations interactions (LGPI) for scientific support; to M. Clark and D. Tracey from NIWA, P. Lorance from Ifremer, R. García Cancela and C. Piñeiro Alvarez from Instituto Español de Oceanografia, and C. Daguin from LGPI, for collecting and providing samples; to R. Daley, B. Innes and R.D. Ward from CSIRO for providing material from reference collections; to L. Broquière and C. Perrin for help with molecular analyses; to C. Coustau, E. Douzery, P. Lehodey, J. Panfili and M. Raymond for helpful discussions, technical tips, or help with bibliographic search; to R.D. Ward for corrections and comments on the manuscript. HALICAL 1 and HALIPRO 2 exploratory surveys were carried out under the patronage of ZoNéCo, a program aimed at assessing the deep fishery resources of the economic zone of New Caledonia. Financial support for laboratory analyses was from IRD (AB 632740) and LGPI (CNRS, université Montpellier-2, and Ifremer URM 16).

\section{References}

[1] Creasey S.S., Rogers A.D., Population genetics of bathyal and abyssal organisms, Adv. Mar. Biol. 35 (1999) $1-151$.

[2] Wilson R.R. Jr, Waples R.S., Distribution, morphology, and biochemical genetics of Coryphaenoides armatus and C. yaquinae (Pisces: Macrouridae) in the central and eastern North Pacific, Deep-Sea Res. 30 (1983) 1127-1145.

[3] Baker C.S., Perry A., Chambers G.K., Smith P.J., Population variation in the mitochondrial cytochrome $b$ gene of the orange roughy Hoplostethus atlanticus and the hoki Macruronus novaezelandiae, Mar. Biol. 122 (1995) 503-509.

[4] Wilson R.R. Jr,Waples R.S., Electrophoretic and biometric variability in the abyssal grenadier Coryphaenoides armatus of the western North Atlantic, eastern South Pacific and eastern North Pacific Oceans, Mar. Biol. 80 (1984) 227-237.

[5] Smith P.J., Genetic similarity between samples of the orange roughy Hoplostethus atlanticus from the Tasman Sea, south-west Pacific Ocean and north-east Atlantic Ocean, Mar. Biol. 91 (1986) 173-180.

[6] Elliott N.G., Smolenski A.J., Ward R.D., Allozyme and mitochondrial DNA variation in orange roughy, Hoplostethus atlanticus (Teleostei: Tratichthyidae): little differentiation between Australian and North Atlantic populations, Mar. Biol. 119 (1994) 621-627.

[7] Busakhin S.V., Systematics and distribution of the family Berycidae (Osteichthyes) in the world ocean, J. Ichthyol. (USSR) 22 (1982) 1-21.

[8] Lehodey P., Grandperrin R., Age and growth of the alfonsino Beryx splendens over the seamounts off New Caledonia, Mar. Biol. 125 (1996) 258.

[9] Lehodey P., Grandperrin R., Marchal P., Reproductive biology and ecology of a deep-demersal fish, alfonsino Beryx splendens, over the seamounts off New Caledonia, Mar. Biol. 128 (1997) 17-27.

[10] Ivanin N.A., On the discovery of a juvenile beryx-alfonsino, Beryx splendens, in the region of the North Australian trough of the Indian Ocean, J. Ichthyol. (USSR) 27 (1987) 171-172.

[11] Roden G.I., Mesoscale flow and thermohaline structure around Fieberling Seamount, J. Geophys. Res. 96 (1991) 16653-16672.

[12] Rogers A.D., The biology of seamounts, Adv. Mar. Biol. 30 (1994) 305-350.

[13] Avise J.C., Molecular Markers, Natural History and Evolution, Chapman \& Hall, London, 1994, 511 p.

[14] Solignac M., Périquet G., Anxolabéhère D., Petit C., Génétique et évolution, II. L'espèce, l'évolution moléculaire, Hermann, Paris, 1995, 367 p.

[15] Maynard Smith J., Evolutionary Genetics, 2nd ed., Oxford University Press, Oxford, 1998, 325 p. 
[16] Wright S., Isolation by distance, Genetics 28 (1943) 139-156.

[17] Rousset F., Genetic differentiation and estimation of gene flow from $F$-statistics under isolation by distance, Genetics 145 (1997) 1228.

[18] Ovenden J.R., Mitochondrial DNA and marine stock assessment: a review, Austr. J. Mar. Freshw. Res. 41 (1990) 835-853.

[19] Smith P.J., Jamieson A., Birley A.J., Electrophoretic studies and the stock concept in marine teleosts, J. Cons. Int. Explor. Mer 47 (1990) 245.

[20] Carvalho G.R., Hauser L., Molecular genetics and the stock concept in fisheries, Rev. Fish Biol. Fisheries 4 (1994) 326-350.

[21] Ward R.D., Grewe P.M., Appraisal of molecular genetic techniques in fisheries, Rev. Fish Biol. Fisheries 4 (1994) 300-325.

[22] Lehodey P., Les monts sous-marins de Nouvelle-Calédonie et leurs ressources halieutiques, thèse de doctorat, université française du Pacifique, Papeete, 1994, $401 \mathrm{p}$.

[23] Lehodey P., Grandperrin R., A study of the fishery and biology of Beryx splendens (alfonsin) in New Caledonia, Fisheries Newslett. 71 (1994) 30-36.

[24] Grandperrin R., Bargibant G., Menou J.L., Campagne HALICAL 1 de pêche à la palangre de fond dans le Nord et sur la ride des Loyauté, en Nouvelle-Calédonie, Conv. Sci. Mer, Biol. Mar. (Orstom, Nouméa) 12 (1995) 1-67.

[25] Grandperrin R., Farman R., Lorance P., Jomessy T., Hamel P., Laboute P., Labrosse P., Richer de Forges B., Séret B., Virly S., Campagne HALIPRO 2 de chalutages exploratoires profonds dans le sud de la zone économique de Nouvelle-Calédonie (R.V. Tangaroa, 4-28 Novembre 1996), Programme ZoNéCo d'évaluation des ressources marines de la zone économique de Nouvelle-Calédonie, Nouméa, 1997, 150 p.

[26] Sambrook J., Fritsch E.F., Maniatis T., Molecular Cloning: a Laboratory Manual, 2nd ed., Cold Spring Harbor Laboratory, New York, 1989.

[27] Kocher T.D., Thomas W.K., Meyer A., Edwards S.V., Pääbo S., Villablanca F.X., Wilson A.C., Dynamics of mitochondial DNA evolution in animals: amplification and sequencing with conserved primers, Proc. Natl. Acad. Sci. USA 86 (1989) 6196-6200.

[28] Palumbi S., Martin A., Romano S., McMillan W.O., Stice L., Grabowski G., The Simple Fool's Guide to PCR, v. 2.0, University of Hawaii, Honolulu, 1991, 47 p.

[29] Hoarau G., Borsa P., Bonhomme F., Grandperrin R., Génétique des populations de Beryx splendens de la zone économique de la Nouvelle-Calédonie: distribution des haplotypes du gène du cytochrome $b$ de l'ADN mitochondrial et analyse phylogénétique de leurs séquences, Doc. Sci. Techn. IRD Noumea Sér II 1 (1999) 1-39.

[30] Orita M., Iwahana H., Kanazawa H., Hayashi K., Sekiya T., Detection of polymorphisms of human DNA by gel electrophoresis as single-strand conformation polymorphisms, Proc. Natl. Acad. Sci. USA 86 (1989) 2766-2770.

[31] Hayashi K., PCR-SSCP - rapid and easy detection of DNAsequence changes, Hum. Cell 5 (1992) $180-184$.

[32] Hayashi K., PCR-SSCP: a simple and sensitive method for detection of mutations in the genomic DNA, PCR Meth. Applic. 1 (1991) 38.

[33] Lessa E.P., Applebaum G., Screening techniques for detecting allelic variation in DNA sequences, Mol. Ecol. 2 (1993) 119-129.

[34] Borsa P., Coustau C., Single-stranded DNA conformation polymorphism at the $R d l$ locus in Hypothenemus hampei (Coleoptera: Scolytidae), Heredity 76 (1996) 124-129.

[35] Desmarais E., Lanneluc I., Lagnel J., Direct amplification of length polymorphisms (DALP), or how to get and characterize new genetic markers in many species, Nucl. Acids Res. 26 (1998) 1458-1465.

[36] Weir B.S., Cockerham C.C., Estimating $F$-statistics for the analysis of population structure, Evolution 38 (1984) 1358-1370..

[37] Reynolds J.,Weir B.S., Cockerham C.C., Estimation of the coancestry coefficient: basis for short term genetic distance, Genetics 105 (1983) 767-779. 
[38] Mantel N., The detection of disease clustering and a generalized regression approach, Cancer Res. 27 (1967) 209-220.

[39] Belkhir K., Borsa P., Goudet J., Chikhi L., Bonhomme F., Genetix v. 3.0, Logiciel sous WindowsTM pour la génétique des populations, laboratoireGénome et population, université Montpellier-2, Montpellier, 1996.

[40] Cabot E.L., Beckenbach A.T., Simultaneous editing of multiple nucleic acid and protein sequences with Esee, Comput. Appl. Biosci. 5 (1989) 233-234.

[41] Swofford D.L., Paup: phylogenetic analysis using parsimony, v. 3.1.1. Illinois Natural History Survey, Champaign, 1993.

[42] Felsenstein J., Confidence limits on phylogenies: an approach using the bootstrap, Evolution 39 (1985) 783-791.

[43] Kumar S., Tamura K., Nei M., Molecular evolutionary genetics analysis: Mega, v. 1.01, Institute of Molecular Evolutionary Genetics, Penn State University, University Park, 1993.

[44] Kimura M., A simple method for estimating evolutionary rate of base substitutions through comparative studies of nucleotide sequences, J. Mol. Evol. 16 (1980) 111-120.

[45] Nei M., Li W.H., Mathematical model for studying genetic variation in terms of restriction endonucleases, Proc. Natl. Acad. Sci. USA 76 (1985) 5269-5273.

[46] Kluge A.G., Farris J.S., Quantitative phyletics and the evolution of Anurans, Syst. Zool. 18 (1969) $1-32$.

[47] Farris J.S., The retention index and homoplasy excess, Syst. Zool. 38 (1989) 406-407.

[48] Grant W.S., Bowen B.W., Shallow population histories in deep evolutionary lineages of marine fishes: insights from sardines and anchovies and lessons for conservation, J. Hered. 89 (1998) 415-426.

[49] Avise J.C.,Walker D., Johns G.C., Speciation durations and Pleistocene effects on vertebrate phylogeography, Proc. R. Soc. Lond. B 265 (1998) 1707-1712.

[50] Gauldie R.W., Biological history and estimation from the zones, checks and microincrements of the otolith of the alfonsin, Beryx splendens (Berycidae), Cybium 19 (1995) 107-129.

[51] Anibal J., Esteves E., Krug H., Marques da Silva H., Age and growth in the alfonsino, Beryx splendens (Berycidae) from the Azores (central eastern Atlantic), Ital. J. Zool. 65 (suppl.) (1998) 215218.

[52] Martin A.P., Palumbi S.R., Body size, metabolic rate, generation time, and the molecular clock, Proc. Natl. Acad. Sci. USA 90 (1993) 4091.

[53] Rand D.M., Thermal habit, metabolic rate and the evolution of mitochondrial DNA, Trends Ecol. Evol. 9 (1994) 125-131.

[54] Koehn R.K., Hilbish T.J., The adaptive significance of genetic variation, Am. Sci. 75 (1987) 134141.

[55] Kotoulas G., Bonhomme F., Borsa P., Genetic structure of the common sole Solea vulgaris at different geographic scales, Mar. Biol. 122 (1995) 361-375.

[56] Borsa P., Naciri M., Bahri L., Chikhi L., García de León F.J., Kotoulas G., Bonhomme F., Zoogéographie infra-spécifique de la mer Méditerranée: analyse des données génétiques populationnelles sur seize espèces atlanto-méditerranéennes (poissons et invertébrés), Vie Milieu 47 (1997) 295-305.

[57] Planes S., Borsa P., Galzin R., Bonhomme F., Geographic structure and gene flow in the manini (convict surgeonfish, Acanthurus triostegus) in the south-central Pacific, in: Beaumont A.R. (Ed.), Genetics and Evolution of Aquatic Organisms, Chapman\&Hall, London, 1994, pp. 113-122.

[58] Borsa P., Blanquer A., Berrebi P., Genetic structure of the flounders Platichthys flesus and $P$. stellatus at different geographic scales, Mar. Biol. 129 (1997) 233-246.

[59] Saavedra C., Zapata C., Guerra A., Alvarez G., Allozyme variation in European populations of the oyster Ostrea edulis, Mar. Biol. 115 (1993) 85-95.

[60] Launey S., Marqueurs microsatellites chez l'huître plate Ostrea edulis L. : caractérisation et application à un programme de sélection pour une résistance au parasite Bonamia ostreae et à l'étude de populations naturelles, thèse de doctorat, Institut national agronomique Paris-Grignon, Paris, 1998, 214 p. 
[61] Borsa P., Jarne P., Belkhir K., Bonhomme F., Genetic structure of the palourde Ruditapes decussatus L. in the Mediterranean, in: Beaumont A.R. (Ed.), Genetics and Evolution of Aquatic Organisms, Chapman \& Hall, London, 1994, pp. 103-113.

[62] Williams S.T., Benzie J.A.H., Evidence of a biogeographic break between populations of a high dispersal starfish: congruent regions within the Indo West Pacific defined by color morphs, mtDNA and allozyme data, Evolution 52 (1998) 87-99.

[63] Diaz-Almela E., Structuration génétique mitochondriale chez l'huître plate Ostrea edulis le long des côtes européennes et comparaison avec la différenciation nucléaire, mémoire de DEA, université Montpellier-2, Montpellier, 1999, $35 \mathrm{p}$.

[64] Palmer A.R., Strathmann R.R., Scale of dispersal in varying environments and its implications for life histories of marine invertebrates, Oecologia 48 (1981) 308-318.

[65] Knowlton N., Sibling species in the sea, Annu. Rev. Ecol. Syst. 24 (1993) 189-216.

[66] Weir B.S., Genetic Data Analysis, Sinauer, Sunderland MA, 1990.

[67] Asmussen M.A., Arnold J., The effects of admixture and population subdivision on cytonuclear disequilibria, Theor. Pop. Biol. 39 (1991) 273-300.

[68] Williams G.C., Natural Selection: Domains, Levels and Challenges, Oxford University Press, New York, 1992, $208 \mathrm{p}$.

[69] Heemstra P.C., Berycidae, in: Smith M.M., Heemstra P.C. (Eds.), Smith's Sea Fishes, SpringerVerlag, Berlin, 1986, pp. 409-410. 
Table I. Beryx splendens. SSCP-haplotype frequencies at the cytochrome $b$ locus for six samples from the economic zone of New Caledonia, and for samples from southeastern Australia, the Chatham Rise off New Zealand, and the Galicia Bank off Spain.

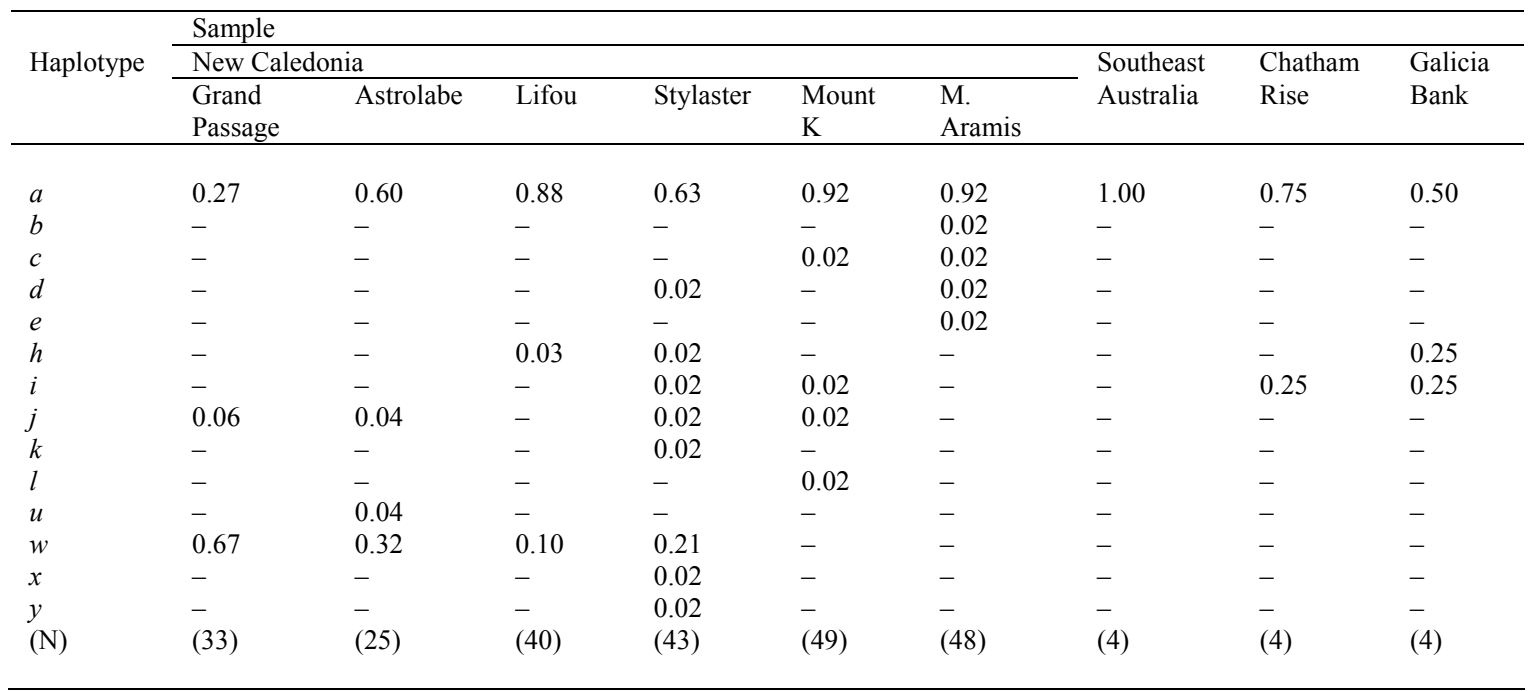

$N$ : sample size. 
Figure 1. Beryx splendens. Sampling sites within the economic zone of New Caledonia. Sampling dates, depths $(z)$, and sample sizes $(N)$ were: Grand Passage: November 1994, $z=575-750 \mathrm{~m}, N=33$;

Astrolabe: December 1994, $z=535-750 \mathrm{~m}, N=30$; Lifou: December 1994, $z=450-793 \mathrm{~m}, N=41$; Stylaster: November 1996, $z=448-880 \mathrm{~m}, N=45$; Mont K: November 1996, $z=935-936 \mathrm{~m}, N=49$; Aramis: November 1996, $z=640-740 \mathrm{~m}, N=49$. (Modified from [26]; the contour line represents depth $600 \mathrm{~m}$ ). Sampling sites not mentioned on this map were southeastern Australia, $N=4$; Chatham Rise off New Zealand: January 1998, $N=4$; Galicia Bank off Spain: April 1998, $z=340-430 \mathrm{~m}, N=4$.

Figure 2. Beryx splendens. Parsimony tree (strict-consensus tree from the 20 most parsimonious trees) inferred from the partial nucleotide sequences of 12 cytochrome $b$ haplotypes $(a, d, e, h, i, j, k, l, u, w, x$, $y$ ) detected by SSCP. Haplotypes $b$ and $c$ are not presented here because their partial sequences were identical to that of haplotype $y$. The cytochrome $b$ gene sequences of two $B$. decadactylus individuals from the Gulf of Biscay [B.d. (Atl)] and southeastern Australia [B.d. (Aus)]were used as outgroup for rooting the tree. Numbers at a tree node are bootstrap scores (in \%), out of 2000 pseudotrees. Only bootstrap scores $\geq 80 \%$ are presented. Scale bar: 1 mutational step. Tree length $=45$ steps; consistency index $[46]=0.84$; retention index $[47]=0.83$.

Figure 3. Beryx splendens. Distribution of pairwise similarity indices, $S \mathrm{XY}=n \mathrm{XY} /(n \mathrm{X}+n \mathrm{Y})[45]$ across individual DALP profiles. Full (resp., open), mtDNA haplotypes of individuals X and Y belonging to the same (resp., different) mitochondrial clade(s) (A or W). 


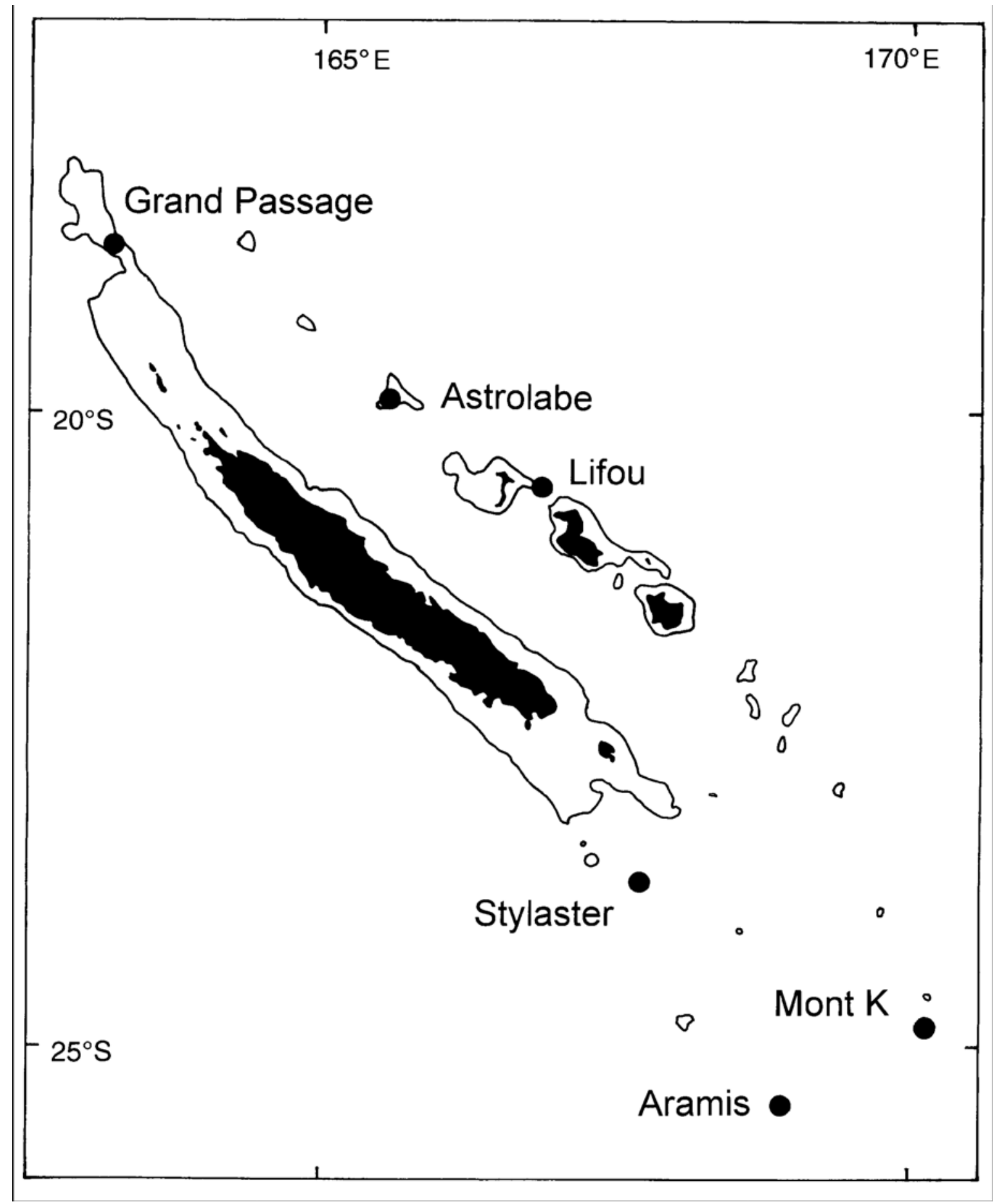




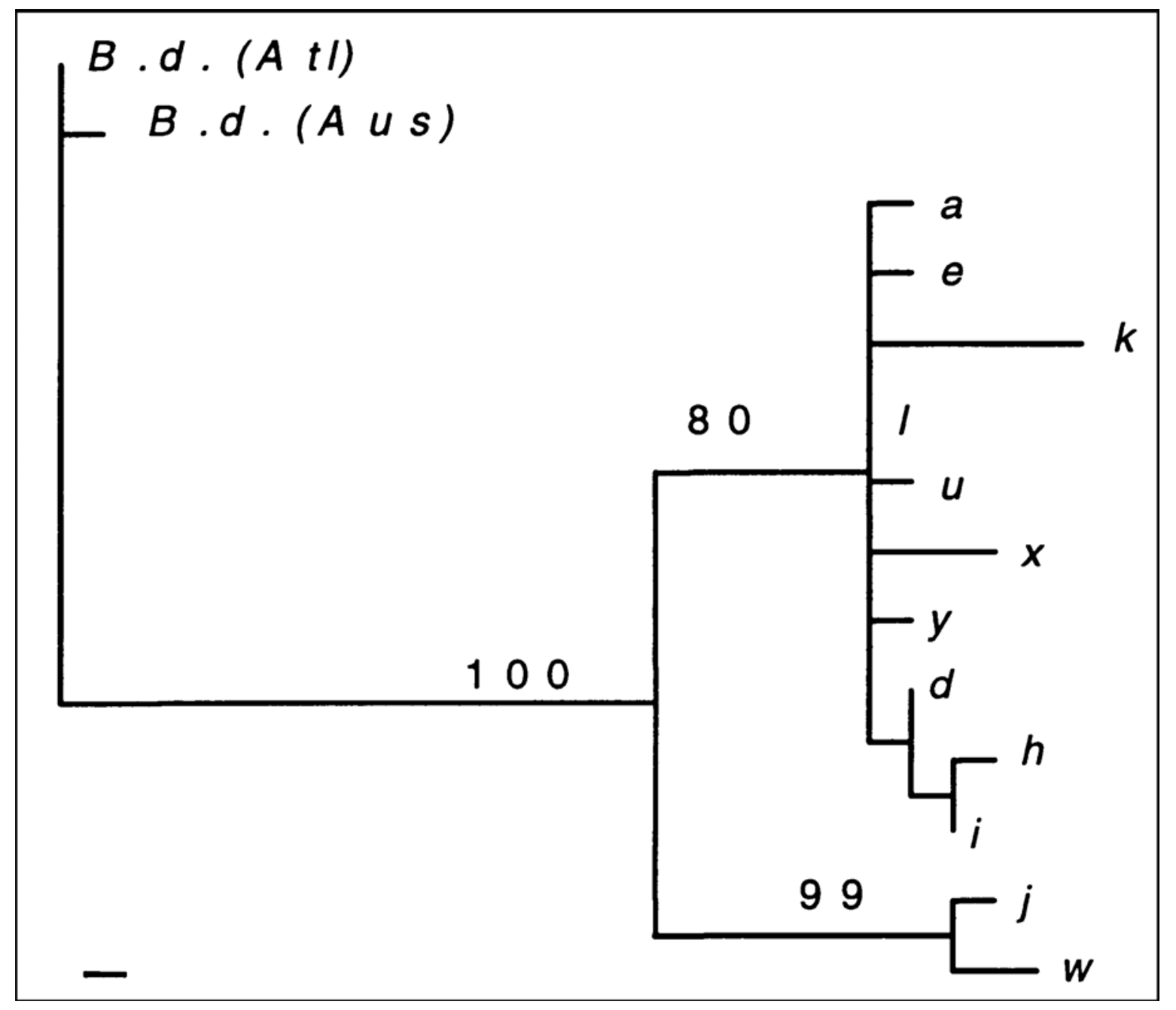




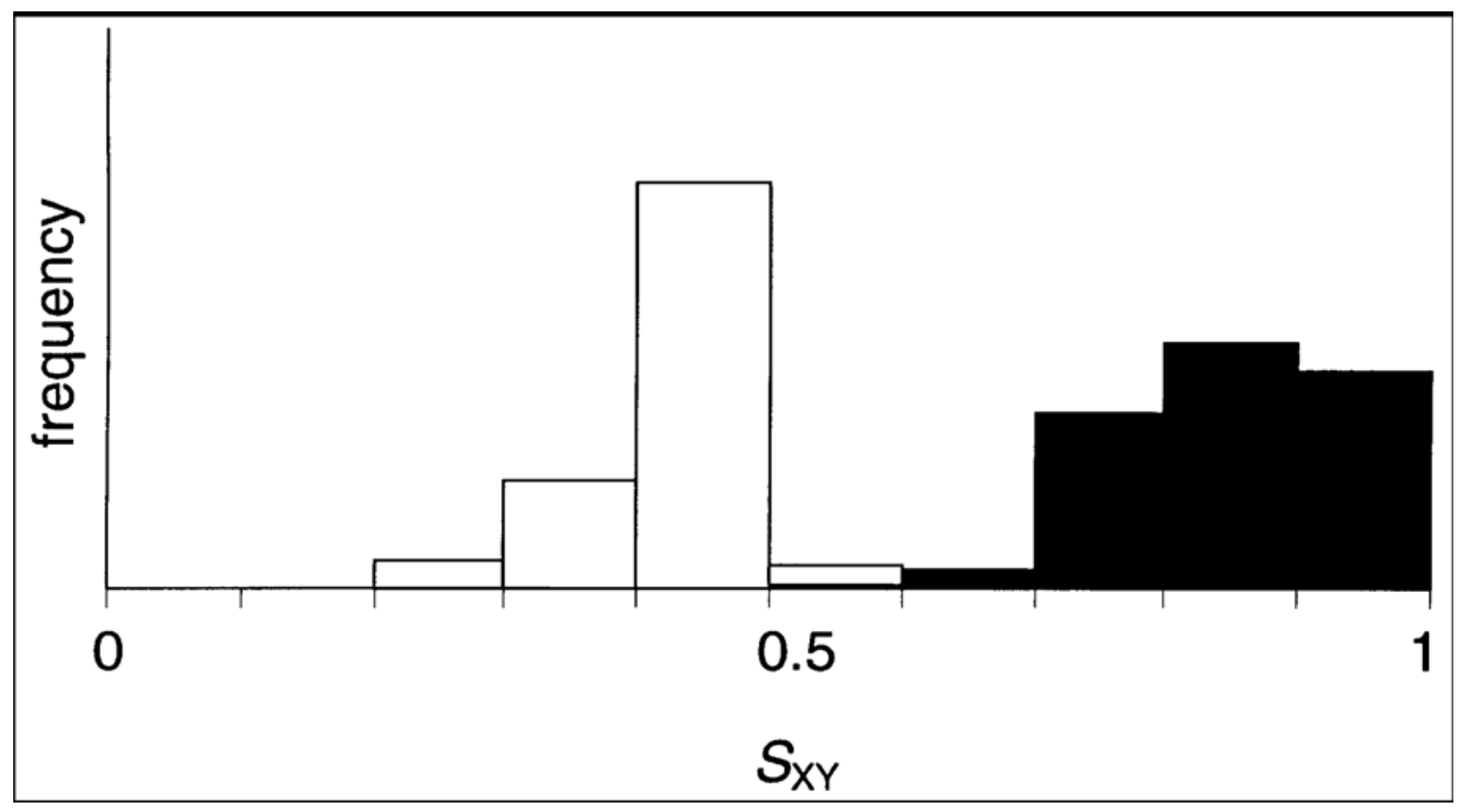

